\title{
Penerapan Pembelajaran Berbasis Laboratorium Virtual untuk Meningkatkan Pengetahuan Peserta Didik Pada Materi Pokok Listrik Dinamis di Kelas IX SMPN 17 Kendari
}

\author{
Risnawati $^{1)}$, Muh. Yuris ${ }^{2)}$, Erniwati $^{2)}$ \\ ${ }^{1)}$ Alumni Jurusan Pendidikan Fisika FKIP UHO, Kendari, Sulawesi Tenggara, Indonesia 93232 \\ ${ }^{2,)}$ Dosen Jurusan Pendidikan Fisika FKIP UHO, Kendari, Sulawesi Tenggara, Indonesia 93232 \\ Email: physed014@gmail.com
}

\begin{abstract}
This study aims to determine the differences and increase students' knowledge on dynamic electric material class IX SMP Negeri 17 Kendari. This research is an experimental research applying virtual laboratory-based learning with class $I X_{3}$ as many as 31 students as experimental class and class $I X_{2}$ as many as 32 students as control class. The results of the study: 1) there is no significant difference between the average value of the initial test of the experimental class students' knowledge and the average value of the initial test of the control class students based on sig. 0.343 is greater than $\alpha=0.05 ; 2)$ the average value of the final test of the knowledge of the experimental class students is significantly higher than the average value of the final test of the control class students based on the value of sig. 0.027 less than $\alpha=$ 0.05; and 3) the average value of $\mathrm{N}$-Gain knowledge of experimental class students is significantly higher than the average value of $N$-Gain knowledge of control class students based on sig values. 0.014 is smaller than $\alpha=0.05$. Thus it can be concluded that students' knowledge can be increased through the use of virtual laboratories.
\end{abstract}

Keyword: Knowledge; Virtual Laboratory; Dynamic Electricity

\begin{abstract}
Abstrak: Penelitian ini bertujuan untuk mengetahui perbedaan dan peningkatan pengetahuan peserta didik pada materi listrik dinamis kelas IX SMP Negeri 17 Kendari. Penelitian ini merupakan penelitian eksperimen yang menerapkan pembelajaran berbasis laboratorium virtual dengan sampel kelas $\mathrm{IX}_{3}$ sebanyak 31 peserta didik sebagai kelas eksperimen dan kelas $\mathrm{IX}_{2}$ sebanyak 32 peserta didik sebagai kelas kontrol. Hasil penelitian: 1) tidak ada perbedaan yang signifikan antara nilai rata-rata tes awal pengetahuan peserta didik yang belajar melalui pembelajaran berbasis laboratorium virtual dan laboratorium konvensional berdasarkan nilai signifikan sebesar $0,343(\alpha=0,05) ; 2)$ nilai rata-rata tes akhir pengetahuan peserta didik kelas eksperimen lebih tinggi secara signifikan daripada nilai rata-rata tes akhir peserta didik kelas kontrol berdasarkan nilai signifikan sebesar 0,027 $(\alpha=0,05)$; dan 3) nilai rata-rata $N$-Gain pengetahuan peserta didik kelas eksperimen lebih tinggi secara signifikan daripada nilai ratarata $\mathrm{N}$-Gain pengetahuan peserta didik kelas kontrol berdasarkan nilai signifikan sebesar 0,014 $(\alpha=0,05)$. Hasil ini mengindikasikan bahwa dengan menggunakan laboratorium virtual dapat meningkatkan pengetahuan peserta didik kelas IX SMP Negeri 17 Kendari pada materi pokok Listrik Dinamis.
\end{abstract}

Kata Kunci: Pengetahuan; Laboratorium Virtual; Listrik Dinamis

\section{PENDAHULUAN}

Ilmu pengetahuan alam (IPA) merupakan cara mencari tahu tentang alam secara sistematis untuk menguasai kumpulan pengetahuan yang berupa fakta-fakta, konsep-konsep, prinsip-prinsip, proses penemuan dan memiliki sikap ilmiah. Pembelajaran IPA tidak hanya sekedar pengetahuan yang bersikap ilmiah saja, melainkan terdapat muatan IPA, keterampilan proses dan dimensi yang terfokus pada karakteristik dan watak ilmiah (BSNP, 2006). Oleh karena itu pembelajaran IPA membutuhkan laboratorium sebagai tempat proses pembelajaran dengan metode praktikum yang dapat memberikan pengalaman belajar pada peserta didik untuk mengaplikasikan teori keilmuan, pengujian teoritis, pembuktian uji coba, penelitian dan sebagainya 
dengan menggunakan alat bantu yang menjadi kelengkapan dari fasilitas dengan kuantitas dan kualitas yang memadai (Depdiknas, 2002).

Laboratorium berfungsi sebagai tempat berlangsungnya kegiatan pembelajaran IPA secara praktek yang memerlukan peralatan khusus yang tidak mudah dihadirkan di ruang kelas. Menurut Sukarso (2005) salah satu fungsi laboratorium adalah sebagai tempat untuk berlatih mengembangkan keterampilan intelektual melalui kegiatan pengamatan, pencatatan dan pengkaji gejala-gejala alam. Sesuai yang tercantum pada Permendiknas No. 41 tahun 2007, maka dalam pelaksanaan pembelajaran seharusnya guru memfasilitasi peserta didik melakukan percobaan di laboratorium.

Menurut badan standar nasional pendidikan (2007) setiap satuan pendidikan wajib memliki sarana dan prasarana laboratorium yang memadai. Namun kenyataan di lapangan, masih banyak sekolah yang belum dilengkapi sarana dan prasarana laboratorium yang memadai. Hal ini berdampak bagi kegiatan pembelajaran IPA di sekolah karena guru akan cenderung kembali menggunakan metode konvensional sehingga hanya fokus pada penyampaian konsep tanpa pengujian ilmiah. Selain itu perencanaan pelaksanaan pembelajaran (RPP) yang disusun berdasarkan kurikulum 2013 tidak terlaksana secara optimal.

Salah satu sekolah yang di survey adalah SMPN 17 Kendari dimana masih minimnya fasilitas laboratorium di sekolah tersebut. Berdasarkan hasil observasi yaitu wawancara bebas dengan guru bidang studi IPA dan peserta didik kelas IX di SMPN 17 Kendari, diperoleh informasi bahwa dalam pembelajaran IPA jarang dilakukan praktikum yang disebabkan oleh sarana dan prasarana yang kurang memadai, keterbatasan waktu, dan target materi sehingga dalam kegiatan pembelajaran peserta didik masih belum sepenuhnya mengerti dengan materi yang telah diajarkan oleh guru karena pengetahuan mereka tentang materi IPA hanya berdasarkan yang disampaikan oleh guru, tanpa ada pengujian yang kuat yaitu berupa praktikum di laboratorium.

Untuk mengatasi masalah kurangnya sarana dan prasarana dalam melakukan praktikum serta mengantisipasi jika laboratorium konvensional tidak memungkinkan untuk digunakan maka dapat diatasi dengan mengintegrasikan teknologi informasi dan komunikasi (TIK) dalam pembelajaran, misalnya program-program simulasi, animasi dan laboratorium virtual yang telah tersedia dapat diunduh melalui akses internet. Salah satu yang paling memungkinkan adalah menggunakan sistem pembelajaran dengan laboratorium virtual (Lerianti, 2014).

Menurut Budiyono (2009), "Laboratorium virtual adalah serangkain alat-alat yang berbentuk perangkat lunak (software) komputer berbasis multimedia interaktif, yang dioperasikan dengan komputer dan dapat mensimulasikan kegiatan di laboratorium seakan-akan pengguna berada pada laboratorium sebenarnya". Dengan adanya laboratorium virtual diharapkan peserta didik dapat melakukan praktikum secara mandiri maupun kelompok tanpa takut alatnya rusak atau habis. Keunggulan laboratorium virtual antara lain adalah bisa menjelaskan konsep abstrak yang tidak bisa dijelaskan melalui penyampaian verbal, dapat menghemat waktu, lebih mudah dan aman digunakan serta memudahkan peserta didik menemukan sendiri konsep-konsep penting dalam IPA. Laboratorium virtual bisa menjadi tempat melakukan eksperimen yang tidak bisa dilakukan di dalam laboratorium konvensional (Ariani dkk, 2010).

Materi listrik dinamis adalah materi IPA yang bersifat abstrak karena peserta didik tidak bisa melihat bagaimana arus listrik mengalir dan bagaimana resistor dapat menghambat arus listrik. Namun materi listrik dinamis juga bersifat konkret karena efek dari arus listrik bisa dirasakan dan diamati. Laboratorium virtual diperlukan dalam proses pembelajaran agar abstraksi dari arus listrik dapat divisualisasikan (Widarti, 2011).

Penelitian yang dilakukan oleh Muhammad dan Sri (2014) menunjukkan bahwa penerapan model pembelajaran langsung dengan media PhET Simulations dapat meningkatkan pemahaman konsep siswa. Penelitian yang dilakukan oleh Muchamad (2016) juga menunjukkan hasil yang sama dengan menyimpulkan bahwa pembelajaran menggunakan media laboratorium virtual meningkatkan hasil belajar siswa.

Berdasarkan uraian diatas, perlu dilakukan penelitian untuk mengetahui sejauh mana pembelajaran berbasis laboratorium virtual dapat meningkatkan pengetahuan peserta didik sehingga disusunlah penelitian yang berjudul Penerapan Pembelajaran Berbasis Laboratorium Virtual untuk Meningkatkan Pengetahuan Peserta Didik pada Materi Pokok Listrik Dinamis di Kelas IX SMPN 17 Kendari.

\section{METODE}

Penelitian ini termasuk jenis penelitian eksperimen. Penelitian eksperimen yang digunakan merupakan penelitian quasi experimental 
(eksperimen semu). Penelitian ini telah dilaksanakan pada semester ganjil tanggal 22 November sampai 1 Desember 2018 tahun ajaran 2018/2019 pada peserta didik kelas IX SMPN 17 Kendari.

\section{Subjek dan Objek Penelitian}

Populasi dalam penelitian ini adalah semua peserta didik kelas IX SMPN 17 Kendari yang terdaftar pada tahun ajaran 2018/2019 yang terdiri dari kelas $\mathrm{IX}_{1}$ sampai kelas $\mathrm{IX}_{6}$. Subjek dalam penelitian ini adalah kelas $\mathrm{IX}_{3}$ dengan jumlah peserta didik 31 orang sebagai kelas eksperimen yang diajarkan menggunakan laboratorium virtual dan $\mathrm{IX}_{2}$ dengan jumlah peserta didik 32 orang sebagai kelas kontrol yang diajarkan menggunakan laboratorium konvensional. Obyek penelitian adalah pengetahuan peserta didik menggunakan pembelajaran berbasis laboratorium virtual untuk materi listrik dinamis

\section{Teknik Pengumpulan Data dan Analisis Data}

Teknik pengumpulan data dalam penelitian ini dilakukan dengan menggunakan instrumen dalam bentuk pilihan ganda yang digunakan untuk mengumpulkan data pengetahuan peserta didik. Tes dilakukan sebanyak dua kali yaitu sebelum kelas diberi perlakuan dan setelah kelas diberi perlakuan.

Desain dalam penelitian ini menggunakan desain the pretest-post-test non-equivalent group design (Cohen dkk, 2007).

Desain penelitiannya dapat digambarkan dengan rancangan sebagai berikut.

\section{$01 \mathrm{X} \quad \mathrm{O2}$}

O3

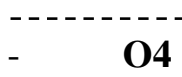

Keterangan:

$\mathrm{O} 1=$ pretest kelas pertama

$\mathrm{O} 2$ = posttest $\mathrm{kelas}$ pertama

$\mathrm{O} 3=$ pretest $\mathrm{kelas}$ kedua

$\mathrm{O} 4$ = posttest $\mathrm{kelas}$ kedua

$\mathrm{X}=$ pembelajaran menggunakan laboratorium virtual

- = pembelajaran menggunakan laboratorium konvensional

--- = kedua kelas terpisah secara paralel

Penelitian eksperimen ini menggunakan dua teknik analisis statistik yaitu analisis deskriptif dan analisis inferensial. Analisis deskriptif merupakan analisis yang digunakan untuk menggambarkan keadaan sampel. Sedangkan Analisis statistika inferensial dimaksudkan untuk menguji hipotesis penelitian. Sebelum pengujian hipotesis, maka terlebih dahulu dilakukan pengujian dasar-dasar analisis sebagai pedoman untuk melakukan uji mana yang akan dipakai. Pengujian dasar-dasar analisis yang digunakan terdiri atas pengujian normalitas data dan homogenitas data.

\section{Prosedur Penelitian}

Langkah-langkah yang ditempuh dalam penelitian ini secara garis besar adalah sebagai berikut.

1. Melakukan observasi awal di SMPN 17 Kendari untuk mengetahui keadaan sekolah, dengan melakukan interview pada guru IPA, serta untuk mengetahui jumlah populasi yang akan dijadikan objek penelitian.

2. Mengidentifikasi, menganalisis, melakukan kajian-kajian teoritis, dan hasil-hasil penelitian terdahulu serta mengajukan hipotesis penelitian.

3. Menyusun perangkat pembelajaran berupa silabus, RPP, dan LKPD.

4. Menyusun instrumen tes berdasarkan kisi-kisi yang telah disusun.

5. Melakukan uji coba tes pada kelas X (yang sebelumnya telah diajarkan materi listrik dinamis untuk menentukan validitas, reliabilitas, daya pembeda, dan tingkat kesukaran setiap item soal).

6. Menganalisis data hasil uji coba untuk mengetahui taraf kesukaran butir soal, daya pembeda butir soal, validitas butir soal dan reliabilitas tes.

7. Pengambilan keputusan tentang instrumen tes berdasarkan karakteristik hasil uji coba.

8. Melakukan pre-test untuk mengetahui pengetahuan peserta didik sebelum pelaksanaan pembelajaran.

9. Melakukan pembelajaran menggunakan bahan ajar laboratorium virtual pada kelas eksperimen dan bahan ajar laboratorium konvensional pada kelas kontrol (masing-masing tiga kali pertemuan).

10. Memberikan post-test untuk mengetahui pengetahuan peserta didik kelas eksperimen dan kelas kontrol setelah pembelajaran selesai.

11. Mengolah dan menganalisis data hasil tes pengetahuan peserta didik.

12. Pembahasan dan penarikan kesimpulan hasil penelitian.

\section{HASIL DAN PEMBAHASAN}

Analisis penelitian kuasi eksperimen ini menggunakan bantuan Microsoft Excel dalam penentuan analisis deskriptif dan software SPSS 16.0 yang mencakup uji prasyarat analisis dan uji hipotesis.

Berdasarkan hasil analisis deskriptif, nilai rata-rata pengetahuan pada materi listrik dinamis peserta didik kelas eksperimen dan kelas kontrol keduanya 


\section{JIPFi}

Jurnal Penelitian Pendidikan Fisika, Vol. 5 No.1 Januari 2020, 65-71

Available Online at http://ojs.uho.ac.id/index.php/JIPFI

p-ISSN: 2502-3861 | e-ISSN: 2715-551X

mengalami peningkatan. Data hasil tes awal dan tes akhir peserta didik kelas eksperimen dan kelas

kontrol dapat dilihat pada Tabel 1.

Tabel 1. Data Hasil Tes Awal dan Tes Akhir Pengetahuan Peserta Didik Materi Listrik Dinamis Kelas Eksperimen dan Kelas Kontrol

\begin{tabular}{lllll}
\hline \multirow{2}{*}{ Nilai } & Kelas Eksperimen & \multicolumn{2}{l}{ Kelas Kontrol } \\
\cline { 2 - 5 } & Tes Awal & Tes Akhir & Tes Awal & Tes Akhir \\
\hline Maksimum & 40 & 95 & 50 & 95 \\
\hline Minimum & 20 & 75 & 20 & 70 \\
\hline Rata-Rata & 30 & 85,97 & 32,03 & 82,03 \\
\hline Stan.Deviasi & 7,071 & 6,76 & 9,576 & 7,055 \\
\hline
\end{tabular}

Pengetahuan peserta didik pada materi listrik dinamis kelas eksperimen dan kelas kontrol

mencapai kategori tinggi, sedang dan rendah. Selengkapnya dapat dilihat pada Tabel 2 .

Tabel 2. Pengkategorian Pengetahuan Peserta Didik Kelas Eksperimen dan Kelas Kontrol pada Materi Listrik Dinamis

\begin{tabular}{|c|c|c|c|c|c|c|c|c|c|}
\hline \multirow{2}{*}{ Nilai } & \multirow{3}{*}{} & \multicolumn{4}{|c|}{ Kelas Eksperimen } & \multicolumn{4}{c|}{ Kelas Kontrol } \\
\cline { 3 - 10 } & & Kategori & \multicolumn{2}{|c|}{ Tes Awal } & Tes Akhir & \multicolumn{2}{c|}{ Tes Awal } & \multicolumn{2}{c|}{ Tes Akhir } \\
\cline { 3 - 10 } & & $\begin{array}{c}\text { f } \\
(\mathbf{o r g})\end{array}$ & $\mathbf{( \% )}$ & $\begin{array}{c}\text { f } \\
(\mathbf{o r g})\end{array}$ & $\mathbf{( \% )}$ & $\begin{array}{c}\text { f } \\
(\mathbf{o r g})\end{array}$ & $\mathbf{( \% )}$ & $\begin{array}{c}\text { f } \\
\text { (org) }\end{array}$ & $\mathbf{( \% )}$ \\
\hline $\mathrm{X}_{\mathrm{i}}>\bar{X}+\mathrm{SD}$ & Tinggi & 6 & 19,35 & 7 & 22,58 & 4 & 12,5 & 8 & 25 \\
\hline $\begin{array}{l}\bar{X}-\mathrm{SD} \leq \mathrm{X}_{\mathrm{i}} \leq \\
\bar{X}+\mathrm{SD}\end{array}$ & Sedang & 19 & 61,29 & 20 & 64,52 & 22 & 68,75 & 21 & 65,63 \\
\hline $\mathrm{X}_{\mathrm{i}}<\bar{X}-\mathrm{SD}$ & Rendah & 6 & 19,35 & 4 & 12,90 & 6 & 18,75 & 3 & 9,38 \\
\hline
\end{tabular}

Kategori $N$-Gain pengetahuan peserta didik pada

kontrol mencapai kategori tinggi dan sedang. materi listrik dinamis kelas eksperimen dan kelas

Selengkapnya dapat dilihat pada Tabel 3

Tabel 3. Pengkategorian Nilai $N$ - Gain Peserta Didik Kelas Eksperimen dan Kelas Kontrol pada Materi Listrik Dinamis

\begin{tabular}{|c|c|c|c|c|c|}
\hline \multirow{3}{*}{ Nilai } & \multirow{3}{*}{ Kategori } & \multicolumn{4}{|c|}{$N-$ Gain } \\
\hline & & \multicolumn{2}{|c|}{ Kelas Eksperimen } & \multicolumn{2}{|c|}{ Kelas Kontrol } \\
\hline & & $f$ & $\%$ & $f$ & $\%$ \\
\hline $\mathrm{N}_{\text {Gain }}>70$ & Tinggi & 26 & 83,87 & 16 & 50 \\
\hline $0,3 \leq \mathrm{N}_{\text {Gain }} \leq 0,7$ & Sedang & 5 & 16,13 & 16 & 50 \\
\hline $\mathrm{N}_{\text {Gain }}<0,30$ & Rendah & - & - & - & - \\
\hline
\end{tabular}

\section{Pembahasan Penelitian}

Pelaksanaan penelitian di SMPN 17 Kendari diawali dengan observasi awal dengan melihat nilai ulangan tengah semester (UTS) peserta didik untuk menentukan kelas mana yang akan dijadikan sebagai sampel penelitian yaitu kelas yang diajar menggunakan laboratorium virtual sebagai kelas eksperimen dan kelas yang diajar menggunakan laboratorium konvensional sebagai kelas kontrol. Langkah selanjutnya adalah memberikan tes awal kepada kedua kelas untuk mengetahui kondisi awal pengetahuan peserta didik. Setelah tes awal dilaksanakan, kegiatan pembelajaran dilaksankan pada kelas eksperimen dan kelas kontrol. Untuk mengevaluasi hasil pembelajaran yang telah dilakukan, maka diadakan tes hasil belajar berupa tes akhir untuk mengukur sejauh mana pemahaman peserta didik setelah dilaksankannya proses pembelajaran.

Data hasil pengetahuan peserta didik kelas eksperimen dan kelas kontrol menunjukkan bahwa kedua kelas mengalami peningkatan dimana pada kelas eksperimen rata-rata tes awal adalah 30 dan rata-rata tes akhir adalah 85,97 sedangkan pada kelas kontrol rata-rata tes awal adalah 32,03 dan rata-rata tes akhir adalah 82,03. Rata-rata tes akhir pengetahuan peserta didik kelas eksperimen lebih baik daripada kelas kontrol.

Hasil analisis uji $N$-Gain menunjukan peningkatan pengetahuan peserta didik kelas 
eksperimen dan peserta didik kelas kontrol. Kategori skor $N$-Gain untuk kelas eksperimen dan kelas kontrol tergolong dalam dua kategori yaitu tinggi dan sedang. Jumlah peserta didik yang mencapai kategori tinggi pada kelas eksperimen adalah 26 orang dan untuk kategori sedang adalah 5 orang sedangkan pada kelas kontrol peserta didik yang mencapai kategori tinggi dan sedang adalah sama yaitu 16 orang. Berdasarkan hasil analisis menunjukan bahwa pengetahuan peserta didik kelas eksperimen lebih baik daripada kelas kontrol.

Hasil analisis uji hipotesis I menunjukkan bahwa secara statistik tidak ada perbedaan yang signifikan antara rata-rata tes awal pengetahuan peserta didik kelas eksperimen dan kelas kontrol dengan nilai sig. (2-tailed) 0,343 lebih besar dari $a=0,05$. Pada pengujian hipotesis II menunjukkan bahwa secara statistik ada perbedaan yang signifikan antara nilai rata-rata tes akhir peserta didik kelas eksperimen dan kelas kontrol atau dapat dikatakan nilai rata-rata tes akhir peserta didik yang belajar menggunakan laboratorium virtual lebih tinggi daripada nilai tes akhir peserta didik yang belajar menggunakan laboratorium konvensional. Hasil ini dapat dibuktikan dengan nilai sig. (2-tailed) yang lebih kecil dari nilai $a=0,05$ yaitu 0,027 . Selanjutnya hasil analisis inferensial terhadap nilai rata-rata $N$-Gain pengetahuan peserta didik kelas eksperimen dan kelas kontrol menunjukkan bahwa secara statistik nilai rata-rata $N$-Gain peserta didik kelas eksperimen lebih baik secara signifikan daripada nilai rata-rata $N$-Gain pengetahuan peserta didik kelas kontrol. Hal ini dapat dilihat dengan nilai sig. (2-tailed) yang lebih kecil dari nilai $a=0,05$ yaitu 0,014 . Hasil penelitian yang telah diperoleh menunjukkan bahwa pembelajaran menggunakan laboratorium virtual dan laboratorium konvensional pada materi listrik dinamis keduanya dapat meningkatkan pengetahuan peserta didik. Pengetahuan peserta didik dari tes awal ke tes akhir meningkat pesat. Terlihat dari $N$-Gain kelas eksperimen dan kelas kontrol yang sangat tinggi. Beberapa faktor yang menyebabkan antara lain: 1) pada tes awal peserta didik masih menggunakan kemampuan awal dan belum menerima materi listrik dinamis sedangkan pada tes akhir peserta didik menggunakan pengetahuan berdasarkan materi yang diberikan; 2) adanya kesamaan soal tes awal dan tes akhir yang dikerjakan sehingga ada kemungkinan peserta didik sudah menghapal jawaban soal yang diberikan; dan 3) jarak pelaksanaan pembelajaran dan tes akhir sangat dekat sehingga materi- materi yang diberikan lebih mudah diingat oleh peserta didik.
Hasil analisis secara statistik menunjukkan bahwa pengetahuan peserta didik menggunakan laboratorium virtual lebih tinggi daripada laboratorium konvensional. Hal ini karena pada kelas yang menggunakan laboratorium virtual, peserta didik dapat menemukan konsep sendiri dan pengetahuan mereka melalui suatu penyelidikan yang dapat dilakukan secara mandiri dan berulangulang sehingga dapat memahami materi listrik dinamis dengan tuntas. Penggunaan laboratorium virtual membuat peserta didik dapat melakukan praktikum secara mandiri maupun kelompok tanpa takut alatnya rusak atau habis.

Laboratorium virtual menyediakan alat percobaan yang lebih praktis dan tersedia dengan menggunakan komputer atau laptop sehingga lebih efisien dalam penggunaan waktu. Menyusun rangkaian percobaan lebih mudah pada media virtual dan lebih aman untuk penggunaannya. Selain itu peserta didik dapat melihat visualisasi bagaimana arus listrik dapat mengalir dan bagaimana resistor dapat menghambat arus listrik. Muzana dan Hasanah (2014) mengatakan bahwa media laboratorium virtual dapat mempermudah siswa untuk melakukan praktikum secara langsung dengan kelompok masing-masing. Keistimewaan tersebut sangat bermanfaat dan sangat bagus untuk meningkatkan keaktifan dan daya tarik siswa untuk belajar. Penyampaian dengan media laboratorium virtual dapat membuat siswa lebih inovatif, kreatif, dan efektif sehingga prinsip utamanya adalah meningkatkan efesiensi efektifitas belajar mengajar disekolah dalam hal penggunaan waktu, dana, fasilitas, dengan tenang, cepat, dan tepat. Dalam hasil penelitian Jagodzinski dan Wolski (2014) mengatakan bahwa pembelajaran menggunakan laboratorium virtual berdampak positif pada peningkatan efisiensi pengajaran, siswa pun mengalami peningkatan dalam mengingat informasi dan menunjukkan daya tahan yang lebih besar dalam mengingat informasi (konsep) materi.

Pembelajaran dengan menggunakan laboratorium konvensional/riil sebenarnya juga dapat memudahkan peserta didik memahami konsep materi listrik dinamis. Terlihat dari pengetahuan peserta didik yang juga meningkat pesat dan bahkan nilai rata-rata pengetahuan kelas eksperimen dan kelas kontrol tidak terpaut jauh. Hal ini disebabkan karena antusiasme peserta didik sangat besar pada ketertarikan alat dan bahan nyata yang dapat membuat peserta didik lebih aktif. Peserta didik dapat merasakan langsung efek adanya arus listrik. Namun pada pelaksanaan pembelajaran banyak ditemukan hambatan atau kendala-kendala, 
diantaranya peserta didik masih bingung dan dihantui perasaaan takut berbuat salah dalam memegang alat-alat laboratorium terutama pada percobaan membuat rangkaian listrik seri dan paralel, serta penggunaan multimeter dalam mengukur besaran listrik. Hal ini membuat proses pembelajaran berlangsung lama dan tidak selesai tepat waktu.

Penerapan pembelajaran berbasis laboratorium virtual pada materi pokok listrik dinamis dapat meningkatkan pengetahuan peserta didik di SMPN 17 Kendari karena dari penelitian yang dilakukan pengetahuan peserta didik yang belajar menggunakan laboratorium virtual lebih tinggi daripada peserta didik yang belajar menggunakan laboratorium konvensional. Penelitian ini relevan dengan penelitian yang telah dilakukan sebelumnya seperti: 1) penelitian yang dilakukan oleh Nur Hikmah, dkk (2017) menunjukkan bahwa penerapan laboratorium virtual pada materi laju reaksi di SMA Negeri 86 Jakarta dapat meningkatkan pemahaman konsep siswa. Data hasil pengamatannya menunjukkan nilai pre-test untuk kelas eksperimen 22,1 dan kelas kontrol 23,10, sementara hasil posttest menunjukkan untuk kelas eksperimen 77,53 dan kelas kontrol yaitu 71,10; dan 2) penelitian yang dilakukan oleh Muhammad Fathul Mubarrok dan Sri Mulyaningsih (2014) di SMP Negeri 7 Bonegoro pada materi cahaya menunjukkan bahwa nilai ratarata kelas eksperimen yang menerapkan model pembelajaran langsung dengan media PhET Simulations adalah 77,30 sedangkan nilai rata-rata kelas kontrol adalah 71,20.

Penggunaan laboratorium virtual maupun laboratorium konvensional/riil pada materi listrik dinamis keduanya sangat berdampak positif terhadap peningkatan pengetahuan peserta didik. Peserta didik sangat antusias dalam mengikuti pembelajaran, hal ini terlihat dengan adanya perhatian yang lebih baik ketika mempelajari materi yang diberikan. Laboratorium virtual dan laboratorium konvensional memiliki kelebihan dan kekurangan masing-masing, namun bisa membantu peserta didik dalam memahami konsep IPA dengan baik. Bagi sekolah yang sudah memiliki sarana laboratorium tetapi alatnya terbatas dapat memanfaatkan laboratorium virtual sebagai alternatif dalam pembelajaran. Guru juga dapat menggunakan laboratorium virtual untuk menjelaskan konsep abstrak yang tidak bisa dijelaskan melalui penyampaian verbal. Dengan adanya PhET yang bisa difungsikan menjadi laboratorium virtual sangat membantu peserta didik dalam meningkatkan pengalaman belajar yang lebih efektif.

\section{KESIMPULAN}

Dari hasil penelitian dan pembahasan yang telah diuraikan diatas dapat ditarik kesimpulan sebagai berikut:

1. Tidak ada perbedaan yang signifikan antara nilai rata-rata hasil tes awal peserta didik kelas eksperimen dan peserta didik kelas kontrol pada materi pokok listrik dinamis berdasarkan nilai signifikansi $0,343>\alpha=0,05$.

2. Nilai rata-rata hasil tes akhir peserta didik kelas eksperimen lebih baik secara signifikan daripada nilai rata-rata hasil tes akhir peserta didik kelas kontrol berdasarkan nilai signifikansi $0,027<\alpha$ $=0,05$.

3. Nilai rata-rata $N$-Gain hasil belajar materi pokok listrik dinamis peserta didik kelas eksperimen lebih baik secara signifikan daripada nilai ratarata N-Gain hasil belajar peserta didik kelas kontrol berdasarkan nilai signifikansi $0,014<\alpha=$ 0,05 .

\section{DAFTAR PUSTAKA}

Anderson, L.W \& Krathwohl, D.R. 2010. Kerangka Landasan untuk Pembelajaran, Pengajaran, dan Asesmen (Revisi Taksonomi Pendidikan Bloom). Pustaka Pelajar. Yogyakarta.

------2015. Kerangka Landasan untuk Pembelajaran, Pengajaran, dan Asesmen (Revisi Taksonomi Pendidikan Bloom). Pustaka Pelajar. Yogyakarta.

Ariani, dkk. 2010. Pembelajaran Multimedia di Sekolah. Prestasi Pustaka Publisher.Jakarta.

Arikunto, S. 2013. Prosedur Penelitian Suatu Pendekatan Praktik Edisi Revisi. Rineka Cipta. Jakarta.

Badan Standar Nasional Pendidikan. 2006. Standar Isi Mata Pelajaran IPA SMP/MTS. Badan Standar Nasional Pendidikan. Jakarta.

-------2007. Standar Proses untuk Satuan Pendidikan Dasar dan Menengah. Kementerian Pendidikan Nasional. Jakarta.

Budhu, M. 2002. Virtual Laboratories for Eingineering Education. Paper Presented at International Conference on Eigeneering Education. Manchester, U.K.

Budiyono. 2009. Penerapan Laboratorium Riil dan Virtual pada Pembelajaran Fisika Melalui Metode Eksperimen Ditinjau dari Gaya Belajar (Studi Kasus pada Madrasah Tsanawiyah Negeri Karangmojo I Kelas III Tahun Ajaran 2008-2009). Tesis. Pascasarjana Universitas Sebelas Maret. Surakarta. 
Cohen, L., Manion, L., \& Morrison, K. 2007. Research Methods in Education $\left(6^{\text {th }} e d.\right)$. Routllege Falmer. London, New York.

Departemen Pendidikan Nasional. 2002. SPTK-21. Departemen Pendidikan Nasional. Jakarta. 2007. Peraturan Menteri Pendidikan Nasional Nomor 41 Tahun 2007 Tentang Standar Proses. Departemen Pendidikan Nasional. Jakarta.

Gunawan et al. 2015. Model Pembelajaran Sains Berbasis ICT. FKIP UNRAM. Mataram.

Haryati, M. 2009. Model dan Teknik Penilaian pada Tingkat Satuan Pendidikan. Gaung Persada Press. Jakarta.

Jagodzinski, P \& Wolski, R. 2014. The Examination of the Impact on Students Use of Gestures While Working in a Virtual Chemical Laboratory for Their Cognitive Abilities. Problem of Education, vol. 61, hlm. 46-57.

Lerianti, E. 2014. Perbandingan Hasil Belajar dengan Menggunakan Laboratorium Nyata dan Laboratorium Virtual dalam Materi Asam Basa Kelas XI IPA SMA Nusantara Kota Jambi. http://103.26.102.47/eskripsi/data/pdf/jurnal_ mhs/artikel/RRA1C10001.pdf, diakses Mei 2018 pukul 18.00.

Meltzer, D.E. 2002. The Relationship Between Mathematics Preparation and Conceptual Learning Gains in Physics: A Possible "Hidden Variable" in Diagnostice Pretest
Scores. American Journal Physics, Vol. 70, hlm. 27.

Muzana, S.R \& Hasanah. 2014. Penerapan Laboratorium Virtual Terhadap Hasil Belajar Fisika pada Materi Rangkaian Arus BolakBalik Siswa Kelas XII SMA Negeri Abulyatama, Vol. 6, hlm. 40.

Subali, B. 2012. Prinsip Assessment dan Evaluasi Pembelajaran. UNY Press. Yogyakarta.

Sudjana. 2002. Metode Statistika. Alfabeta. Bandung.

Sugiyono. 2010. Metode Penelitian Pendidikan Pendekatan Kuantitatif, Kualitatif dan $R \& D$. Alfabeta. Bandung.

-2014. Metode Penelitian Pendekatan Kuantitatif, Kualitatif dan $R \& D$. Alfabeta. Bandung.

2015. Statistik Nonparametris untuk Penelitian. Alfabeta. Bandung.

Sukarso. 2005. Pengertian dan Fungsi Laboratorium. http://wanmustafa. wordpress.com/2011/06/12/pengertian-danfungsi-laboratorium/, diakses pada tanggal 14 April 2018 pukul 21.00.

Widarti, A. 2011. Pembelajaran Fisika Model Siklus Belajar (Learning Cycle) Menggunakan KIT LIstrik Magnet dan Animasi Komputer Ditinjau dari Gaya Belajar dan Kemampuan Berpikir Abstrak Siswa. Tesis. Pascasarjana Universitas Sebelas Maret. Surakarta. 